\title{
REPORT ON THE SELECTION \\ OF A DWARFING ROOTSTOCK FOR CHERRIES
}

\author{
J. FLOOR \\ Institute of Horticultural Plant Breeding, Wageningen \\ Received 24 Jan. 1957
}

\section{INTRODUCTION}

The advantages of dwarfing cherry trees might be considerable. Management, including picking, spraying and pruning would then be much easier. Moreover there is at least some chance that their less vigorous growth might make them less susceptible to bacterial canker; also the protection against starlings by covering them with nets might perhaps be feasible. Therefore the selection of a dwarfing rootstock for cherries was given first priority.

This paper gives a report on the selection for low vigour in Limburgse boskriek, an indigenous Mazzard, and also on the search for a weak growing Prumus species which is compatible with cherries.

\section{SELECTION IN LIMBURGSE BOSKRIEK}

It has been assumed that weak growth of seedlings of Limburgse boskriek is due to unfavourable growing conditions. There may however be a chance of a rare exception in which weak growth is determined by genetical factors. Therefore weak growing seedlings, about 6,000 in all, were selected in the field from various places. Of these plants the percentage bark in the roots was determined as this value has proved a useful criterion of vigour. This is illustrated by the following example. The percentages bark in the roots of the dwarfing apple rootstock M.IX, the moderately vigorous M.II and the very vigorous M.XVI are 67, 51 and 40 respectively. The percent. bark has been determined as follows (7). A sample of roots, slightly less than $10 \mathrm{~mm}$ in diameter was taken from the most vertically growing roots of each seedling. Thin slices from these roots were cut off with a knife and measured under a microscope with a weak magnification by means of a micrometer. The percent. bark is calculated from the measurements as follows. If $\mathrm{A}$ and $\mathrm{B}=$ two diameters of the whole root taken at right angles to each other, and $a$ and $b=$ two diameters of the wood in the same directions, then the percent. bark is given by $100-\frac{100 \mathrm{ab}}{\mathrm{AB}}(7)$.

The result was that from all 6,000 seedlings only 3 plants had a percentage of bark slightly less than 50 . In comparison the percentage bark of the vigorous rootstock F12/1 was 28 , the average of 10 determinations. The first mentioned plants proved to be of the acid type, in other words crosses of Prunus cerasus. It was found unnecessary to keep them for further research, firstly because they would very likely be too vigorous and secondly they might have less favourable characters due to inbreeding with cerasus. That is why in practice such "acid" types are being discarded. The results 
obtained suggest that the chances of selecting a dwarfing Prunus avium are very small or nil.

\section{TESTING VARIOUS PRUNUS SPECIES AS A ROOTSTOCK}

In 1948 Wijnkers and Meikers (May Duke) were each budded on to 15 rootstocks of the following species: Prunus besseyi, Prunus cerasus (Leitzkauer Pressauer, Stockton Morello and Westerlese kriek), Prunus incisa, Prunus padus, Prumus pumila, Prunus serotina, Prunus tenella, Prunus tomentosa, Prunus virginiana and Prunus wadai. It was found unnecessary to include Prunus mahaleb, as this species, due to its deep rooting habits, is not suited to our soils. There are other disadvantages but they could possibly be overcome by selection. As a rule bud take was extremely bad. The few shoots that developed could easily be broken off the rootstock, thus showing a severe form of incompatibility between the scions and the species tried as rootstocks. There were however two exceptions, viz. Prunus cerasus and Prunus incisa. Bud take was better, although not really good and at least in the first years, no symptoms of incompatibility could be observed. For reasons to be explained later Prunus cerasus has been discarded to concentrate further research on Prunus incisa. It appeared from a study of the literature (3, 6, 8 and 9) that a given combination of scion and rootstock can be compatible enough for horticultural purposes and yet fail entirely under less favourable growing conditions. Thus HowARD (8) wrote: "From the very first the union between Morello and the sweet cherry varieties seems insecure. As the trees become older they invariably overgrow the stock and look as though they would surely break off, but they never do". According to GrubB (4) however the same Stockton Morello showed a high degree of incompatibility with sweet cherries. This is no exception. Other fruit species are also markedly influenced by the growing conditions as may be illustrated by a few examples. Under English conditions quince C. is a useful rootstock for pears (10). HiLKENBÄUMER (6) on the other hand states that quince $C$. is "so unverträglich mit Edelsorten und frostempfindlich, dass man seinen Anbau in Mittel-Europa nicht mehr verantworten kann". The same author (5) writes about a pear which holds an intermediate position as regards its compatibility with quince: "Lucas ist an ungünstigen Standorten stark unverträglich, dagegen auf den der Birne und Quitte zusagenden Boden gesund". Furthermore HiLkenBÄUMER (5) states: "Der Einfluss des Standortes auf das Ausmass der Verträglichkeit ist bei Pflaumen so erheblich, dass einzelne Unterlagen, wie z.B. Ackermann, die sich besonders gegensätzlich unter verschiedenen Lebensbedingungen verhalten, noch für bestimmte Standorte brauchbar sind." The information gathered points to the conclusion that the prospects of Prunus cerasus as a rootstock for sweet cherries are not very hopeful. Meanwhile a few cherries on Prunus incisa as a rootstock were received from Mr. S. G. A. Doorenbos. These plants showed a good union between scion and rootstock as can be seen in figure 1. It has therefore been decided to pursue the search for a dwarfing stock in this direction. Provided that further proof of compatibility can be obtained it seems likely that Prunus incisa will meet all requirements as a rootstock. According to Collingwood Ingram (2): "No cherry is more immune from disease or so seldom attacked by pests." The same author cites E. H. WILSON who once wrote: "No cherry is more hardy, more floriferous..."

Propagation should not present any difficulties. For three years the author rooted 

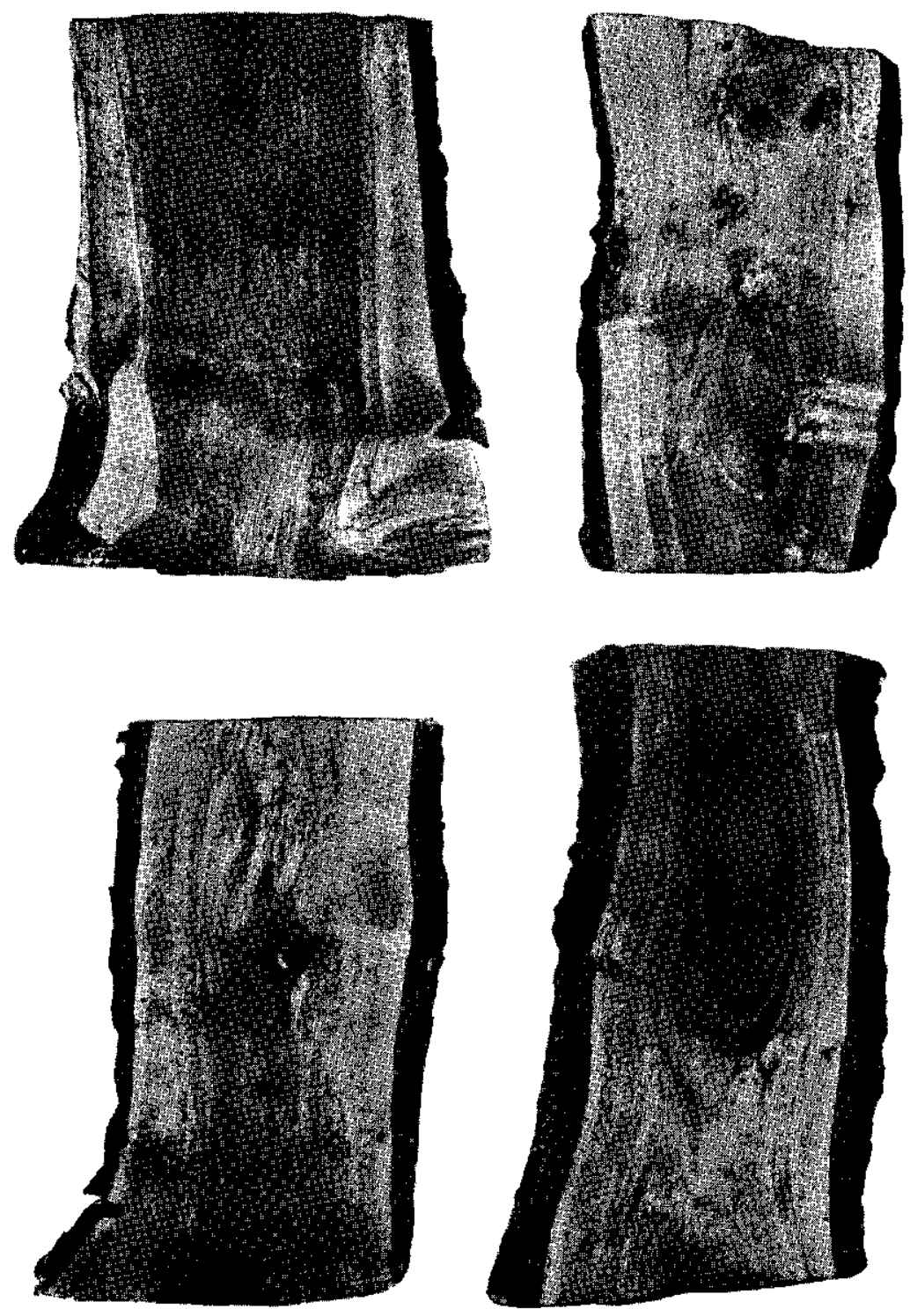

Fig. 1. SECTION OF THE UNION OF EARLy RIVERS WITH PRUNUS INCISA 


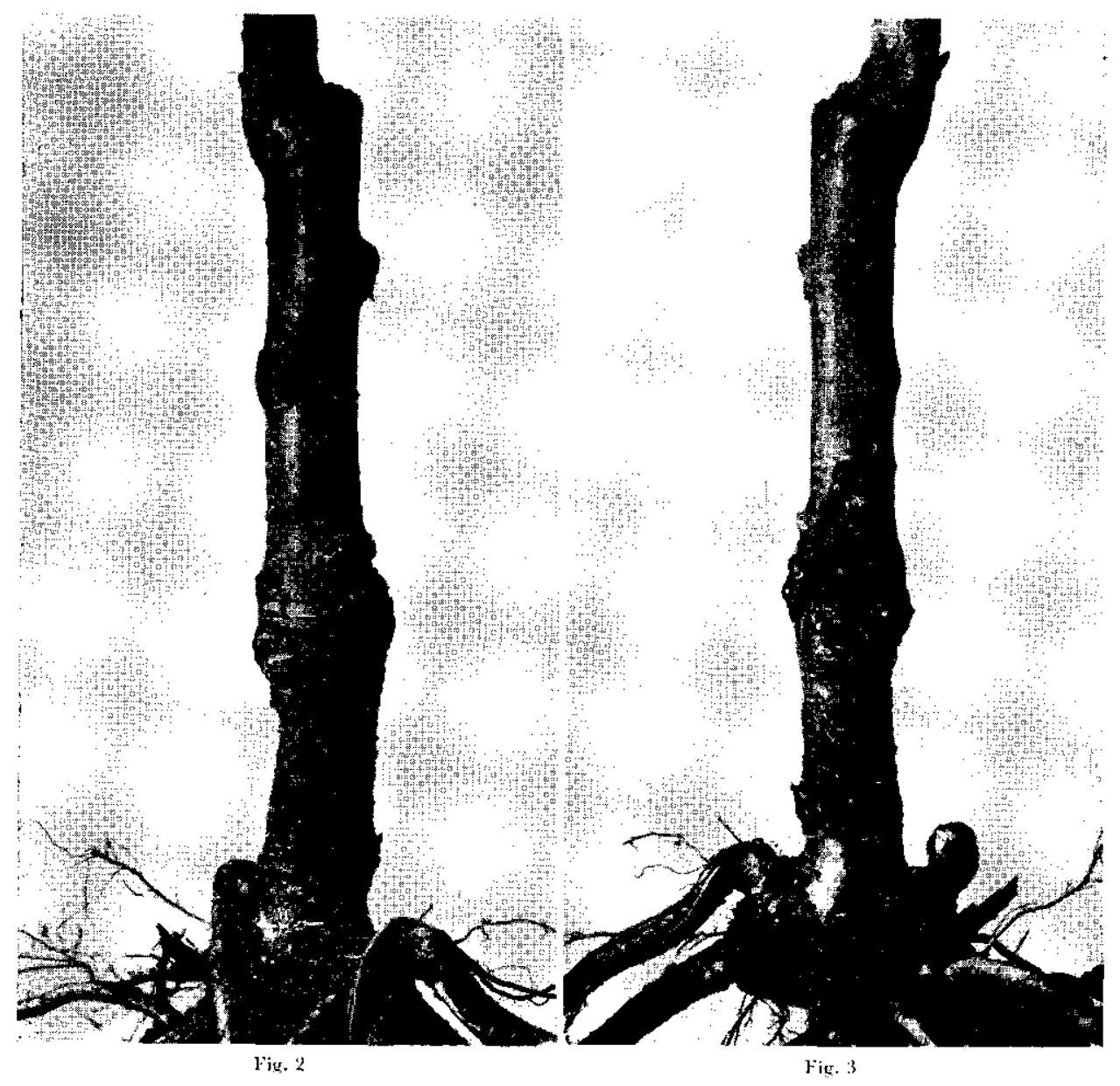

FIG. 2. UNION OF EARLY RIVERS WITH PRUNUS KURILENSIS

Fig. 3. Same plant as in figure 2, but the union seen from the side of the SNaG 
softwood cuttings of Prunus incisa and Prunus kurilensis under mist with practically 100 per cent success. In addition there were indications that propagation by the etiolation method of layering is also possible.

\section{SELECTION IN PRUNUS INCISA AND PRUNUS KURILENSIS}

There were indications that the above mentioned cherries on Prunus incisa were too vigorous. Therefore further selection in Prunus incisa was found desirable. It was not easy to find initial material, because, as stated by Collingwood Ingram, Prunus incisa readily crosses with other Prunus species. For this reason most seedlings of this species are actually hybrids and therefore of stronger growth than the pure species. At first selection was carried out in seedlings of Prunus incisa, resulting in 5 plants with a percentage bark in the roots higher than 50 . These plants were discarded when seeds were received from Mr. S. G. A. DoOREnBos of Prunus incisa compacta, a weak growing form of this species. At the same time Mr. Doorenbos provided scions and seeds from two different bushes of Prunus kurilensis, a cherry of still weaker growth than Prunus incisa. Collingwood IngRam states that he has a specimen of Prunus kurilensis in his collection which is over 20 years old and still under 3 feet high. Meanwhile our plants of Prunus kurilensis proved to be not so very dwarf growing. Yet many seedlings of this species flowered in the spring of 1954, one year after sowing. All seedlings were planted out and budded with Early Rivers in the following summer. Plants that were too small were grafted or budded with the same variety a year later. A total of 69 budded rootstocks of Early Rivers on Prunus incisa compacta and 104 on both forms of Prunus kurilensis were obtained. Thirty per cent of these were 2 years old but in the severe winter of 1956 the one year wood was frozen except for a few buds just above the union, so they may also be considered one year old. The plants were lifted in the autumn of 1956 to carry out a preliminary selection. All plants were tested for compatibility by attempting with some force to break them at the union. Eight out of 69 cherries on Prunus incisa and 24 out of 104 on Prunus kurilensis did not withstand this treatment. It was possible to break these plants because the union was defective on one side. In no case has a clean break been observed. Not all of the 141 remaining plants showed an equally good union between scion and rootstock, but in some selections the union was perfect as far as could be judged by the eye (Figs 2 and 3). It is planned to plant the bushes out under not too favourable orchard conditions to subject them to a reasonably severe test for compatibility. Root cuttings were taken from all plants to obtain an initial stock for rapid propagation if required. Before and after lifting, observations were made on growth, fruit bud formation and root system. The length of the 2-yr "budlings" which were partially frozen, averaged $1.60 \mathrm{~m}$; the average length of 1-yr "budlings" was 1.35 $\mathrm{m}$ with fairly large deviations (Fig. 4). Fruit buds occurred as shown in table 1. 


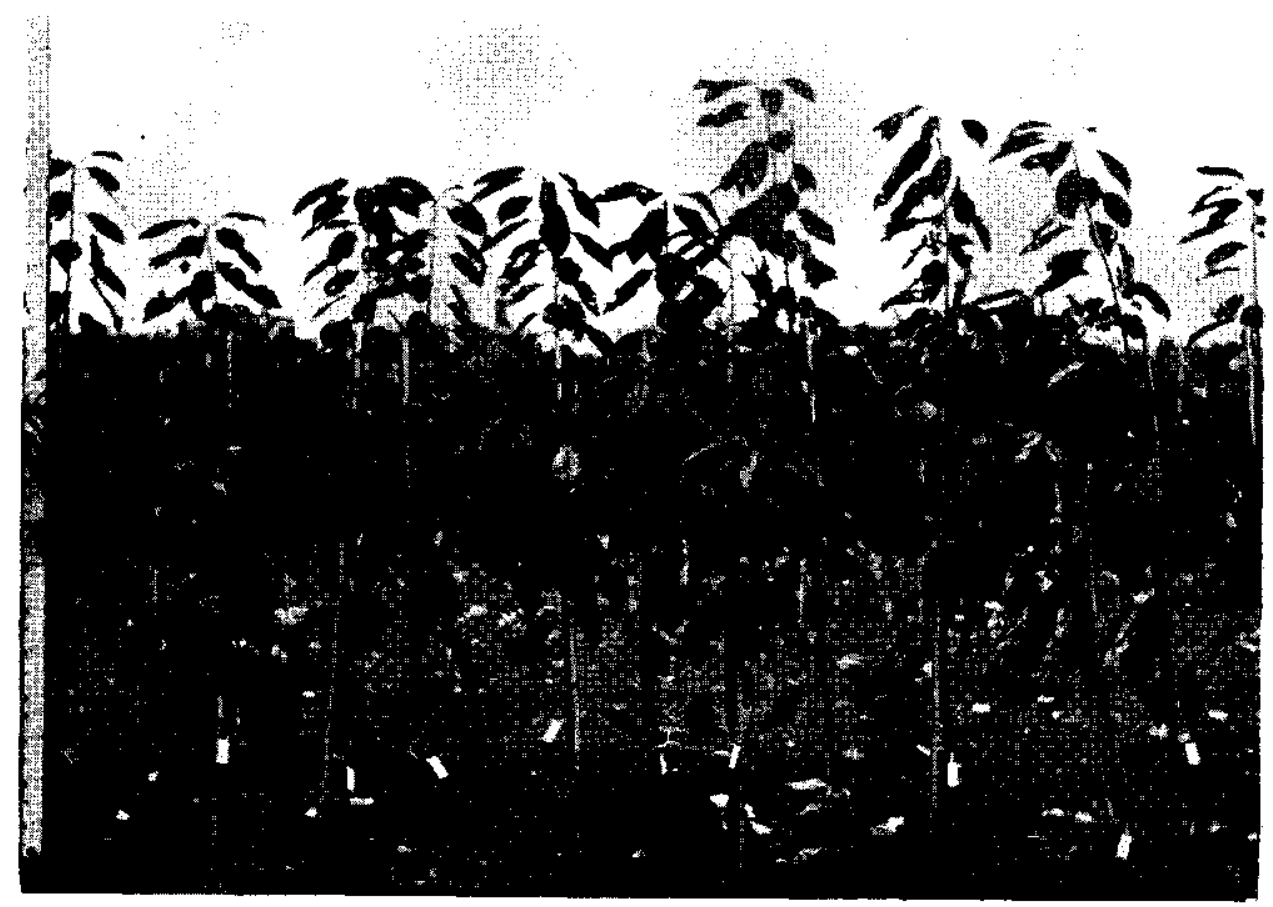

Fig. 4. ONe and two year budded cherries of Early Rivers on Prunus incisa

TABle 1. SURVEY OF THE NUMBER OF FRUIT BUDS ON THE ONE YEAR WOOD OF EARLY RIVERS ON PRUNUS INCISA AND PRUNUS KURILENSIS AS ROOTSTOCKS

\begin{tabular}{|c|c|c|c|c|c|c|c|c|}
\hline \multirow{2}{*}{ Selections } & & \multirow{2}{*}{ Number } & \multirow{2}{*}{$\begin{array}{c}\text { Defective } \\
\text { union }\end{array}$} & \multirow{2}{*}{ Rest } & \multicolumn{4}{|c|}{ Number of fruit buds } \\
\hline & & & & & 0 & $1-5$ & $5-10$ & $10-13$ \\
\hline Prunus incisa . . . & . & 69 & 8 & 61 & 12 & 42 & 6 & 1 \\
\hline Prunus kurilensis I. . & . . & 35 & 5 & 30 & 8 & 18 & 4 & 0 \\
\hline Prunus kurilensis II . & . . . & 69 & 19 & 50 & 9 & 31 & 8 & 2 \\
\hline
\end{tabular}

Finally observations were also made on the root-system. The distribution of the roots varied from all-sided to one-sided. In only a few cases was the root system definitely one-sided. Generally the root system was flat, but some selections had deeper rooting habits. In a few cases a combination of the two was observed. Furthermore great differences in the amount of fibre were observed. Only a few plants suckered.

Summarizing it can be said that the results so far obtained justify the expectation that the selections under investigation will yield a useful dwarfing rootstock for cherries Their weak growth and exceptionally early fruit bud formation may make them also useful for breeding work.

\section{ACKNOWLEDGEMENT}

The author wishes to express his sincere gratitude to Mr. S. G. A. Doorenbos for the invaluable gift of plant material of Prunus incisa and Prumus kurilensis. 


\section{SUMMARY}

The search for a weak growing form of Prunus avium met with no success. Tests in which various weak growing Prunus species were tried as a rootstock led to selection in Prunus incisa and Prunus kurilensis. Early Rivers on seedlings of these species made good growth with fruit buds on the one year wood. To judge from observations of one and two year old unions, the selection of a compatible rootstock shows promise. It has been pointed out that this selection may also be useful for breeding work.

\section{SAMENVATTING}

\section{Verslag van het onderzoek naar een zwakgroeiende onderstam voor kersen}

De selectie in zaailingen van Limburgse boskriek heeft geen planten opgeleverd die van belang geacht kunnen worden voor verder onderzoek. Daarentegen hebben oculeerproeven van kersen op verschillende Prunus-soorten geleid tot selectie in Prunus incisa en Prunus kurilensis. Zodoende werden een aantal planten verkregen waarmede Early Rivers als 1- en 2-jarige oculatie een goede vergroeiing vertoont. Reeds op het éénjarige hout van deze planten werden bloemknoppen waargenomen.

Genoemde selecties worden nader beproefd als zwakke onderstam voor kersen. Naar verondersteld wordt zullen zij ook goede diensten kunnen bewijzen bij veredelingswerk.

\section{REFERENCES}

1. Beakbane, A. B. and Thompson, E. C., Anatomical studies of stems and roots of hardy fruit IV. The root structure of some clonal apple rootstocks budded with Cox's orange Pippin. $J$. Pomol. 33 (1947): 206-211.

2. Collingwood Ingram, Ornamental cherries, 1948.

3. Day, L. H., Cherry Rootstocks. California Agr. Axp. Sta. Bul. 725 (1951): 14-16.

4. Grubb, N. H., Cherries, 1949. p. 11-12.

5. Hilkenbaumer, F., Die gegenseitige Beeinflussung von Unterlage und Edelreis bei den Hauptobstarten im Jugendstadium unter Berücksichtigung verschiedener Standortsverhältnisse. KühnArchiv 58 (1942): 1-261.

6. HilkenbäUmer, F., Obstbau, 1953, p. 65.

7. Hill, R. and BeAKBANe, A. B., The application of biological observations on wild and naturalized species and varieties of fruit trees to the study of fruit tree rootstocks. A prelimanary study of some Prunus species. J. Pomol. 23 (1947): 117-133.

8. Howard, W. L., The Stockton Morello cherry. Proc. Am. Soc. Hort. Sc. 21 (1924): 320-324.

9. Rogers, W. S., General review of research work. E. Malling Res. Sta. for 1948 (1949), p. 23.

10. Fruit Tree Raising. Bul. 135. Min. Agr. Fish. 1946, p. 7. 
70. Banga, O. De ontwikkeling van de rassensituatie bij groentegewassen. Oktober 1955

71. Bruyne, A. S. de. Tendenzen in de ontwikkeling van het Nederlandse fruitsortiment. Oktober 1955

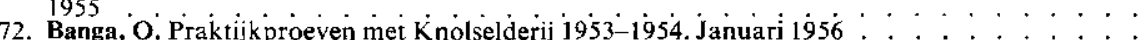

73. Floor, J. Proeven met stekken onder waterverneveling. April 1956

74. Andeweg, J. M. en J. H. Ruyten. Praktijkproeven met Tomaten 1954-1955. April 1956

75. Andeweg, J.M. en A.van Steenbergen.Praktijkproeven met Stoksnijbonen 1953-1954. Mei 1956

75. Andeweg, J.M. en A.van Steenbergen.Praktijkproeven met Stoksnijbonen $1953-1954$. Mei 1956

77. Smeets, L. and Hester G. Kronenberg. Runner formation on stra iberry plants in autumn and Smeets, $\dot{L}$. Runner formation on strawberry plants in autumn and winter. Il. Infiuence of the light intensity on the photoperiodical behaviour. Juni 1956

78. Smeets, L. Influence of the temperature on runner production in five strawberry varieties. Juni 1956 .

79. Smeets, L. and L. M. Wassenar. Problems of heat spot in Fragaria vesca $\mathbf{L}$. when indexing strawberry selections for viruses. Juni 1956 .

80. Banga, $O$ and J. W. de Bruyn. Selection of carrots for carotene content. III Planting distances and ripening equilibrium of the roots. Juni 1956 . - . - ind in the standardization of vegetable varieties at Wageningen, Netherlands on August 26 and 27, 1955 . Augustus 1956

32. Floor, J., P. A. Wezelenburg en H. H. van Doesburg. Proeven met vermeerdering van houtige gewassen. September 1956

33. Gerritsen, C.J. Improvement of the cherry varieties used in the Netherlands. Oktober 1956

34. Gerritsen, C. J. Research offered new possibilities for nut growing in the Netherlands. Oktober 1956

35. Andeweg, J. M. The breeding of scab-resistant frame cucumbers in the Netherlands. Oktober 1956

86. Zeilinga, A. E. An improved acetic orcein squash method for serial cytologicai preparations.

87. Braak, J. P. and $\mathbf{L}$. Smeets. The phytotron of the Institute of Horticultural Plant Breeding at 88. Banga. O and L. Smeets. Some effects of the photoperiod on growth and pithiness of radishes. Oktober 1956

89. Kho, Y. O. and $\mathbf{J}, \dot{\mathbf{P}}$. Braak. Reduction in the yield and viability of carrot seed in relation to the

90. Terpstra, W. Some factors influencing the abscission of debladed leaf petioles. Oktober 1956

91. Keuls, M. en J. J. Post. Invloed van de temperatuur op de groei van asperges. Januari 1957

92. Smeets, L. Some effects of the photoperiod on the shoot growth of cherry seedlings. Februari 1957

93. Elzenga, $\mathbf{G}$, and $\mathbf{J}$. $\mathbf{W}$, de Bruyn. Interrelation of alkaloid content and stage of development of 1 - and 2-year-old Atropa belladonna L. Februari 1957

94. Elzenga, G., L. Smeets and J. W. de Bruyn. Influence of the temperature on growth and alkaloid content of first-year Atropa belladonna L. Februari 1957 . . . . . . . . . . . . . .

95. Ferguson, J. H. A. Some applications of binomial probability paper in genetic analyses. Februari 1957

96. Jensma, J. R. Teelt en veredeling van bloemkool. Maart $1957^{*} \cdot{ }^{*}$

97. Boom, B. K. Benaming, geschiedenis en kenmerken van een aantal houtachtige planten. Nomenclature, history and characteristics of some woody plants. Maart 1957

98. Gerritsen, C. J. De Feyoa, een nieuw cultuurgewas? A pril 1957

99. Braak, J.P. Effects of some internal and external factors on the embryo and seedling development of the cherry seedling. April 1957

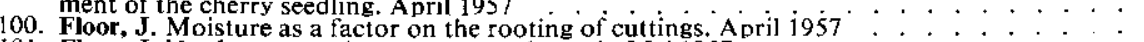

101. Floor, J. Verslag van onderstammen-onderzoek. Mei 1957

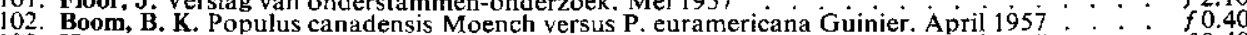

103. Huyskes, J. A. Moet Nederland groene en of yezelvrije asperges gaan telen? Mei 1957 f 0.40

104. Andeweg, J. M. en A. van Steenbergen. Praktijkproeven met tuinbonen 1955-1956. Mei 1957. f 0.40

105. Banga, O. Origin of the European cultivated carrot . . . . . . . . . . . .

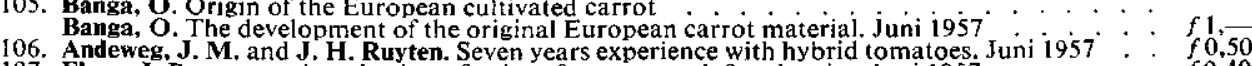

107. Floor, J. Report on the selection of a dwarfing rootstock for cherries. Juni 1957. . . . . . f 0.40

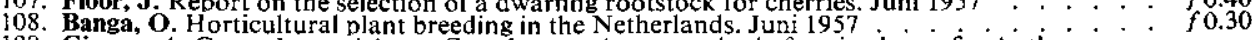

109. Giessen. A. C. van der, and A. van Steenbergen. A new method of testing beans for Anthracnose. Juni 1957

1) Zolang de voorraad strekt kunnen deze publikaties franco worden toegezonden, na ontvangst van het vermelde bedrag op giro no, 425340 van het Instituut voor de Veredeling van Tuinbouwgewassen, $D r$. S. $L$. Mansholtlaan 15 te Wageningen onder vermelding van wat verlangd wordt; ook bestaat de mogelijkheid deze publikaties uit de bibliotheek van het I.V,T, te lenen. 